\title{
On the origins and foundations of Laplacian determinism
}

\author{
Marij van Strien
}

Studies in History and Philosophy of Science, 45(1), March 2014, pp. 24-31

In this paper I examine the foundations of Laplace's famous statement of determinism in 1814, and argue that rather than derived from his mechanics, this statement is based on general philosophical principles, namely the principle of sufficient reason and the law of continuity. It is usually supposed that Laplace's statement is based on the fact that each system in classical mechanics has an equation of motion which has a unique solution. But Laplace never proved this result, and in fact he could not have proven it, since it depends on a theorem about uniqueness of solutions to differential equations that was only developed later on. I show that the idea that is at the basis of Laplace's determinism was in fact widespread in enlightenment France, and is ultimately based on a re-interpretation of Leibnizian metaphysics, specifically the principle of sufficient reason and the law of continuity. Since the law of continuity also lies at the basis of the application of differential calculus in physics, one can say that Laplace's determinism and the idea that systems in physics can be described by differential equations with unique solutions have a common foundation.

\section{Laplace's statement of determinism}

Histories of determinism in science usually start with the following quote, from Laplace's Essai philosophique sur les probabilités (1814):

An intelligence which, for one given instant, would know all the forces by which nature is animated and the respective situation of the entities which compose it, if besides it were sufficiently vast to submit all these data to mathematical analysis, would encompass in the same formula the movements of the largest bodies in the 
universe and those of the lightest atom; for it, nothing would be uncertain and the future, as the past, would be present to its eyes. (Laplace, 1814, p. 3-4). ${ }^{1}$

Throughout history, there have been many people arguing for the general idea that everything that happens is necessary or predetermined. The importance of this quote by Laplace lies in the fact that it is not merely an expression of everything in nature being fixed and everything that occurs being necessary, but that it states that prediction is possible through mathematical analysis, on the basis of the forces and the "respective situations of the entities" that are present. It seems that Laplace is stating a fact about physics, namely that the fundamental equations of physics can be solved in principle (although not necessarily in practice) and then give a unique prediction of future states. This suggests that everything is fixed according to laws of physics of a mathematical form, and that it is physics that tells us that the world is deterministic. (Laplace, by the way, did not use the word "determinism", which only received its current meaning later on; see Hacking (1983)).

An interpretation of what Laplace had in mind would then be the theorem that for all systems in classical physics, there are equations of motion of the form

$$
\frac{d^{2} r}{d t^{2}}=F(r)
$$

with $r$ the position of a body and $F(r)$ the force to which it is subjected, and that these equations have a unique solution for given initial conditions $r\left(t_{0}\right)=r_{0}$ and $\frac{d r}{d t}\left(t_{0}\right)=$ $v_{0}$. This means that if we know the positions and velocities of all particles at a certain instant, and all the forces that are present, we can uniquely determine the future (as well as past) states of the system. This is nowadays the canonical formulation of determinism in classical physics (see e.g. Landau and Lifshitz, 1976, pp. 1-2; Arnold, 1989 , p. 4, 8). ${ }^{2}$ Whether it holds is a different issue: in particular Earman (1986) and Norton (2008) have shown that there are various cases in which this determinism breaks down. But it is usually supposed that this is what Laplace had in mind when he wrote the above statement.

In this paper I examine in how far this interpretation of Laplace's statement holds, and put forward an alternative interpretation, according to which Laplace's determinism is based on general principles, rather than derived from the properties of the equations of mechanics: specifically, it is based on the principle of sufficient reason

\footnotetext{
1 "Une intelligence qui pour un instant donné, connaîtrait toutes les forces dont la nature est animée, et la situation respective des êtres qui la composent, si d'ailleurs elle était assez vaste pour soumettre ces données à l'analyse, embrasserait dans la même formule, les mouvements des plus grands corps de l'univers et ceux du plus léger atome: rien ne serait incertain pour elle, et l'avenir comme le passé, serait présent a ses yeux." ${ }^{2}$ One can make a distinction, however, between determinism and predictability: the equation of motion plus initial conditions may uniquely determine future states of the system, but that does not necessarily mean that we can calculate these future states (see Earman, 1986, p. 7). Laplace did not make this distinction; rather, he made a distinction between predictability in principle and in practice.
} 
and the law of continuity. This does not mean that Laplace's determinism is unrelated to developments in physics, but the relation is not as straightforward as one may suppose.

In section 2, I discuss the possible foundations of Laplace's deterministic statement in his mechanics. I show that Laplace could not have proven that the equations of motion in mechanical systems always have a unique solution, since this depends on a theorem about uniqueness of solutions to differential equations that was only developed later on (furthermore, the theorem left a possibility for indeterminism open). In section 3, I discuss the philosophical argument that Laplace provides for his determinism: in fact, the only motivation that he explicitly gives for his determinism is Leibniz' principle of sufficient reason. In section 4, I show that there was a strong eighteenth century background to Laplace's ideas: he was far from the first to argue for determinism, and also far from the first to do so in terms of an intelligence with perfect knowledge and calculating capacities. Tracing out these connections makes it possible, in section 5 , to get a better understanding of the foundation of Laplace's determinism and the relation with the possibility of mathematical descriptions of nature.

\section{The physical foundations of Laplace's determinism}

One reason to question the interpretation that Laplace's determinism is based on the idea that there are equations of motion for mechanical systems which always have a unique solution for given initial conditions, is that he never argues for this explicitly; he never makes the argument more explicit than in the above quote. And in this quote, the argument is not formulated very carefully: he does not explicitly say that the equations of mechanics always have a unique solution for given initial conditions, and if this is what he intended to argue, then it is striking that he fails to mention that besides the initial positions of all bodies, one also needs to know their initial velocities in order to solve the equations. Furthermore, from the context of this quote, it appears that he was not trying to say something about the properties of the theory of mechanics. Rather, he was arguing for the importance of probability theory: the above statement appeared in the preface of a work on probability theory, in which Laplace argues that the use of probability theory is not restricted to cases in which there is fundamental chance or randomness. He argues that with perfect knowledge of the present state of the universe, it should be possible to predict future states with certainty; however, in all cases in which our knowledge is less than perfect, we have to rely on probability theory. Thus, it 
is because of our ignorance that we have to take recourse to probability theory, even though at the bottom of things, there is a solid necessity. ${ }^{3}$

The idea that certain prediction should be possible on the basis of perfect knowledge of the present state of the universe is something that Laplace had considered before. While his 1814 quote has become famous, he already made a similar statement many years earlier, in a lecture in 1773 (printed in 1776), at the very beginning of his career. The statement is made in a similar context, to clarify the notions of necessity and probability, but it is formulated in less physical terms and does not refer to mathematical analysis or calculation, and it is less apparent that it has a foundation in physics:

...if we conceive an intelligence which, for a given instant, encompasses all the relations between the beings of this universe, it may determine, for any time in the past or the future, the respective position, the motions, and generally the affections of all those beings. (Laplace, 1773, p. 144). ${ }^{4}$

Despite the fact that Laplace did not explicitly demonstrate that the equations of motion always have a unique solution, one may want to argue that he simply knew that this was the case; one may even want to argue that this was so obvious to him that he did not think further demonstration was needed. However, it is not that easy to show that the equations of motion always have a unique solution. In fact, such a demonstration depends on a theorem about the existence and uniqueness to differential equations that was only developed later on: therefore, Laplace could have no proof available.

The first person to work on the issue of existence and uniqueness of solutions to differential equations was Cauchy, who showed in the 1820's that an equation like [1] has a unique solution if $F(r)$ is continuously differentiable (Kline, 1972, p. 717). In 1876, Lipschitz gave a more precise analysis, by showing that the function $F(r)$ does not necessarily have to be continuously differentiable in order for an equation like [1] to have a unique solution; it is enough if it fulfils the condition that there is a constant $K>0$ such that for all $r_{1}$ and $r_{2}$ in the domain of $F$,

$$
\left|F\left(r_{1}\right)-F\left(r_{2}\right)\right| \leq K\left|r_{1}-r_{2}\right| .
$$

(Lipschitz, 1876). This condition came to be known as 'Lipschitz continuity'.

\footnotetext{
${ }^{3}$ As Daston (1992) shows, earlier authors on probability theory such as Jakob Bernoulli and De Moivre also argued for determinism, with a similar aim (but in different terms).

4 "...si nous concevons une intelligence qui, pour un instant donné, embrasse tous les rapports des êtres de cet Univers, elle pourra déterminer pour un temps quelconque pris dans le passé ou dans l'avenir la position respective, les mouvements, et généralement les affections de tous ces êtres."

The lecture is very mathematical; this statement is placed right in the middle. According to Hahn (2005), this shows that Laplace did not assign an important role to metaphysics and that he wanted to be foremost regarded as a mathematical physicist (Hahn, 2005, p. 53). Hahn also points out the use of the word êtres which suggests that it applies to all beings (also living ones).
} 
These mathematical results imply that the equations of motion of a classical system can fail to have a unique solution if they involve a force which is not Lipschitz continuous. This fact has recently been used by Norton (2008) to argue that determinism can fail in classical mechanics; but it was already noted a couple of times before, most notably by Boussinesq in (1879) (see Van Strien, 2014). In (1806), several years before Laplace's famous statement of determinism in 1814, Poisson already discussed the possibility that the equations of motion of a system in physics fail to have a unique solution. One of the cases he discussed was that of a body subjected to a force $F(r)=c r^{a}$ with $c$ and $a$ constants, and $0<a<1$, and with initial conditions $r_{0}=0$ and $v_{0}=0$; this force is non-Lipschitz continuous at $r=0$ and the equation therefore fails to have a unique solution: the body can either remain still at $r=0$ or it can start to move at an arbitrary time (the same example is used by Malament $(2008$, p. 801) as an example of indeterminism in classical physics). Poisson argued that in cases in which the equation of motion did not have a unique solution, one had to make sure to pick the right solution: in the above case, because the force acting on the body at $t=0$ is zero, it makes sense to expect the body to stay put (Poisson, 1806, p. 104). Therefore, to know the actual motion of the body, it is in certain cases not enough to study the equations; these have to be supplemented by additional considerations. The answer to the question whether the laws of mechanics always have a unique solution was not all that evident.

Laplace and Poisson knew each other well, Poisson having been a student of Laplace (O'Connor and Robertson, 2002); it is not known whether Laplace read Poisson's (1806) paper, but this could well have been the case, as the subject of the paper was one that interested both. In any case, Laplace knew that it was possible for differential equations to fail to have a unique solution: he himself had worked on so-called singular solutions to differential equations (Laplace, 1772b), which was an issue in pure mathematics that had been explored before him by among others Clairaut, Euler, and D'Alembert (Kline, 1972, p. 477). It may well be that Laplace had an intuition that such singular solutions would not occur in actual systems in physics; however, the question is then where this intuition came from, for Laplace had no mathematical foundation for it.

One may argue that Laplace knew that the equations that he actually encountered and worked with in his physics always had a unique solution; but also this is not entirely clear. Laplace devoted a large part of his life to celestial mechanics, and argued that it was in this domain that the human mind made the closest approach to his hypothetical intelligence:

The human mind offers, in the perfection which it has been able to give to astronomy, a feeble sketch of this intelligence. Its discoveries in mechanics and geometry, added to that of universal gravity, have brought it within reach to comprehend in the same analytical expressions the past and future states of the system of the world. By applying the same method to some other objects of its knowledge, it has managed to reduce the observed phenomena to general laws, 
and to foresee those phenomena which given circumstances ought to produce. (Laplace, 1814, p. 4). ${ }^{5}$

In celestial mechanics, it had become possible to make very accurate predictions: as an example, Laplace mentioned Halleys' prediction of the return of a comet in 1759 (Laplace, 1814, p. 5). Therefore, the successes in celestial mechanics supported the idea of determinism. At the same time, it was clear to Laplace that even in the case of celestial mechanics, the gap between the human abilities and those of the Laplacian intelligence could never be closed. In particular, the equations of motion tended to become immensely complicated, and Laplace had to work hard to find approximate solutions to differential equations that could not be solved exactly (on his work in celestial mechanics, see Morando, 1995). Even a simple system such as the three body system could not be solved exactly. In "Recherches sur le calcul intégral et sur le système du monde" (1772a), he introduced some new methods for approximate solutions to the equations for the motion of planets, remarking:

It is primarily in the application of mathematical analysis to the system of the world that there is a need for simple and convergent methods to integrate differential equations by approximation; in fact, those of the motion of celestial bodies present themselves in such a complicated form that they leave no hope that we will ever succeed in integrating them rigorously... (Laplace, 1772a, p. 369). ${ }^{6}$

But although the differential equations in astronomy can get enormously complicated and can usually not be solved exactly, they are still of a relatively simple kind, at least as long as you treat the celestial bodies as point masses, and it seems reasonable to expect them to have unique solutions. It is in other areas of physics that things get more messy. In particular, it is not evident that the equations of motion have a unique solution when there are discontinuities in the variables. And discontinuities could arise in various problems in physics, for example in collisions of hard bodies, and the analysis of the vibrating string. ${ }^{7}$

\footnotetext{
5 "L'esprit humain offre dans la perfection qu'il a su donner à l'astronomie, une faible esquisse de cette intelligence. Ses découvertes en mécanique et en géométrie, jointes à celle de la pesanteur universelle, l'ont mis à portée de comprendre dans les mêmes expressions analytiques, les états passés et futurs du système du monde. En appliquant la même méthode à quelques autres objets de ses connaissances, il est parvenu à ramener à des lois générales, les phénomènes observés, et à prévoir ceux que des circonstances données doivent faire éclore."

6 "C'est principalement dans l'application de l'Analyse au système du monde que l'on a besoin de méthodes simples et convergentes, pour intégrer par approximation les équations différentielles; celles du mouvement des corps célestes se présentent, en effet, sous une forme si compliquée, qu'elles ne laissent aucun espoir de réussir jamais à les intégrer rigoureusement..."

${ }^{7}$ In the case of the vibrating string, Laplace agreed with Euler that 'discontinuous' functions had to be admitted in the mathematical treatment of the problem (we would now call these functions continuous with discontinuous derivatives), although it appears from his discussion that these functions did not necessarily
} 
Laplace could thus not provide a mathematical proof of the statement that the equations of physics always had a unique solution, and his determinism could not fully be derived from the properties of the equations of physics.

\section{The philosophical foundations of Laplace's determinism}

Whereas Laplace did not provide a mechanical or mathematical derivation of his statement of determinism, he did in fact provide a philosophical argument. In the passage from which the quote at the beginning of this paper is taken, Laplace argues that all occurrences in nature, both on large and small scale, are a necessary consequence of the laws of nature, ${ }^{8}$ and then goes on to argue:

Current events are connected with preceding ones by a tie based upon the evident principle that a thing cannot come to existence without a cause which produces it. This axiom, known as the principle of sufficient reason, extends even to the most indifferent acts. The most free will cannot give rise to these indifferent acts without a determinative motive; for if, in two cases with exactly similar circumstances, the will acted in the one and refrained from acting in the other, its choice would be an effect without a cause. It would then be, says Leibniz, the blind chance of the Epicureans. The contrary opinion is an illusion of the mind which, losing sight of the evasive reasons of the choice of the will among indifferent things, convinces itself that it has determined itself independently and without motives.

We ought then to regard the present state of the universe as the effect of its anterior state and as the cause of the one which is to follow. An intelligence which... (Laplace, 1814, p. 3). ${ }^{9}$

\footnotetext{
have physical significance: he argued that a system in which there are discontinuities is always infinitely close to another system in which there are no discontinuities. See Laplace (1779, pp. 81-83), Truesdell (1960, p. 293).

8 "Tous les événements, ceux même qui par leur petitesse, semblent ne pas tenir aux grandes lois de la nature, en sont une suite aussi nécessaire que les révolutions du soleil."

9 "Les événements actuels ont avec les précédens, une liaison fondée sur le principe évident, qu'une chose ne peut pas commencer d'être, sans une cause qui la produise. Cet axiome connu sous le nom de principe de la raison suffisante, s'entend aux actions même les plus indifférentes. La volonté la plus libre ne peut sans un motif déterminant, leur donner naissance; car si toutes les circonstances de deux positions étant exactement les mêmes, elle agissait dans l'une et s'abstenait d'agir dans l'autre, son choix serait un effet sans cause: elle serait alors, dit Leibnitz, le hasard aveugle des épicuriens. L'opinion contraire est une illusion de l'esprit qui perdant de vue, les raisons fugitives du choix de la volonté dans les choses indifférentes, se persuade qu'elle s'est déterminée d'elle-même et sans motifs. Nous devons donc envisager l'état présent de l'univers, comme l'effet de son état antérieur, et comme la cause de celui qui va suivre. Une intelligence qui..."
} 
For Laplace, determinism seems to be intimately linked with causation. It is ultimately based on a principle which he calls the principle of sufficient reason: "a thing cannot come to existence without a cause which produces it."10

The principle of sufficient reason plays an important role in the work of Leibniz, whom Laplace mentions two sentences later, and who preceded Laplace in arguing for determinism on metaphysical grounds. Leibniz takes this principle to be one of the two principles on which reason is founded (the other being the principle of contradiction) (Leibniz, 2007 [1710], p. 421). Leibniz' principle of sufficient reason states that for everything that happens there must be a reason which determines why it is thus and not otherwise. ${ }^{11}$ Laplace uses the word "cause" instead of "reason"; these words could have equivalent meanings, but it is important to note that in Laplace, a cause is productive of the event that it brings about, it is an efficient cause in the sense of Aristotle, whereas Leibniz' principle of sufficient reason has more to do with final causation. Thus, there is an important distinction: whereas Leibniz' principle of sufficient reason says that for everything that occurs there must be a reason why it is thus and not otherwise, Laplace's principle of sufficient reason says that for everything there must be a cause that brings it about. In this sense, Laplace's principle of sufficient reason is closer to that of Spinoza: like Laplace, and in contrast with Leibniz, Spinoza does not involve final causation in his discussion of the principle of sufficient reason (Melamed and Lin, 2013).

Laplace thinks of a cause as immediately preceding its effect, and this leads to the conclusion that the present state of the universe should be regarded as the cause of the state of the universe at the next instant. An intelligence with perfect knowledge of the present state of the universe would thus have perfect knowledge of the cause of the universe at a next instant, and under the assumption that causes uniquely determine their effects and it is possible to know the connections between cause and effect (an assumption that Laplace does not state explicitly), this intelligence would have perfect knowledge of the state of the universe at the next instant. By extension, it would have perfect knowledge of all the future and past states of the universe.

This idea, that because of the principle of sufficient reason, perfect knowledge is possible in principle, has parallels with Leibniz' definition of the principle of sufficient reason in the Theodicy: "there is no true enunciation whose reason could not be seen by one possessing all the knowledge necessary for its complete understanding" (Leibniz, 2007 [1710], p. 421). In a sense, Laplace gives a temporal dimension to this statement, by stating that the knowledge necessary for the complete understanding of an event can be located at the previous instant (or, through induction, at any other instant in time).

\footnotetext{
10 "une chose ne peut pas commencer d'être, sans une cause qui la produise".

11 "nothing happens without its being possible for someone who understands things well enough to provide a reason sufficient to determine why it is as it is and not otherwise" (Leibniz, 1714, p. 262).
} 
Thus, the argument that Laplace provides for his determinism is based on an interpretation of the principle of sufficient reason, rather than on the equations of mechanics. On this basis, Israel (1992, p. 259) remarks that Laplace's determinism is "a metaphysical causalism à la Leibniz". The fact that Laplace's argument for determinism is not based on mechanics, however, does not mean that it is completely unrelated to uniqueness of solutions to equations in mechanics. As we have seen from the quote at the beginning of section 1, Laplace thinks that perfect prediction is ultimately possible on the basis of mathematical analysis, which implies that ultimately, there are fundamental laws of nature, of a mathematical form, which always have a unique solution for given initial conditions. His argument for determinism gives metaphysical support to this idea, and motivates the search for such laws. Specifically, the idea that the state of the universe is the cause of the state at the next instant supports the idea that differential equations with unique solutions can be found which describe natural processes. However, the connection between these two ideas is not entirely clear, and Laplace does not discuss how they relate. By looking at the context in which Laplace's determinism appeared, we can get a more complete understanding of its foundations, and of the link between the metaphysics of the principle of sufficient reason and the mathematics of differential equations.

\section{Laplacian determinism before Laplace}

Although Laplace is usually pointed out as the first proponent of scientific determinism, he was by far not the first to argue for determinism in a scientific context. Neither was he the first to argue that an intelligence with perfect knowledge and calculating capacities would be able to predict the future states of the universe with certainty. In this section, I show that this idea came up several times before Laplace, and usually in a philosophical context. In fact, this seems to have been an idea that was widespread around the time that Laplace first expressed it in 1773, particularly in France. Variations of this idea can be found in Maupertuis (1756, p. 332), Boscovich (1922 [1763], p. 281), Condorcet (1768, p. 5), D'Holbach (1770, p. 51-52), and an undated fragment in the archives of Diderot (in Diderot, 1951, p. 255). ${ }^{12}$ With the exception of Boscovich, the

\footnotetext{
${ }^{12}$ Wolfe (2007, p. 38) already indicates that "Laplacian" determinism already appeared before Laplace, mentioning Condorcet and D'Holbach; Wolfe (2012) in addition mentions the fragment in Diderot (1951). Hahn (2005, p. 58) discusses the connection with Condorcet and writes "The notion of an Intelligence with vast calculating powers was familiar to Leibniz, Maupertuis, and Condorcet. Determinism itself was far from novel, having been expressed in various ways by Leibniz and the Jesuit scientist Boscovich before him." (He gives no references). Furthermore, Stiegler (1974) points to Leibniz and Boscovich as proto-Laplacian determinists.
} 
context is philosophical rather than physical, and it appears that the idea did not come out of physics.

For example, D'Holbach, in his Système de la nature ou des lois du monde physique et du monde moral (1770), argues that nothing happens without a cause, that causes are necessarily connected with their effects, and that everything that happens is connected through a chain of causation. He writes that even in a storm or in a whirlwind of dust, there is not a single molecule for which there is no sufficient reason why it is at one place rather than at another:

A geometrician, who would exactly know the different forces which act in these two cases, and the properties of the molecules that are moved, could demonstrate, that, according to given causes, each molecule acts precisely as it ought to act, and could not have acted otherwise than it does. (D'Holbach, 1770, p. 51-52). ${ }^{13}$

There is a great similarity between Laplace's and D'Holbach's statements; whereas Laplace (1814) writes about an intelligence with calculating capacities and perfect knowledge of the forces and the "respective situations of beings", D'Holbach writes about a geometrician with perfect knowledge of the forces and the "properties of molecules". D'Holbach, however, does not write that such a geometrician could make perfect predictions, but that it could demonstrate that each molecule acts as it ought to act and that its motion is thus uniquely determined.

However, D'Holbach's determinism is not limited to physics, and does not seem to be based on physics either. In the case of a storm or a whirlwind of dust, knowledge of the forces that are present and of the properties of the molecules suffices to know how each molecule will act, but in general, the laws according to which cause and effect are connected do not have to be laws of physics, but can also be laws of human behaviour, for example. ${ }^{14}$ D'Holbach writes that "Nature, in all its phenomena, acts necessarily according to the essence which is proper to it; all the beings which it contains act necessarily according to their particular essences" (D'Holbach, 1770, p. 50). ${ }^{15}$ This is a Spinozist view (see Schliesser (forthcoming) on essences in Spinoza). D'Holbach continues to write that, just as in a storm or in a whirlwind of dust, not a single molecule moves by chance, so in a society, the acts of individual men are all determined, even in the whirlwind of a political revolution:

\footnotetext{
13 "Un géometre, qui connoîtroit exactement les différentes forces qui agissent dans ces deux cas, \& les propriétés des molécules qui sont mues, démontreroit que, d'après des causes données, chaque molécule agit précisément comme elle doit agir, \& ne peut agir autrement qu'elle ne fait."

${ }^{14}$ About the necessary laws according to which everything around us happens, D'Holbach writes: "D'après ces loix les corps graves tombent, les corps légers s'élevent, les substances analogues s'attirent, tous les êtres tendent à se conserver, l'homme se chérit lui-même, il aime ce qui lui est avantageux dès qu'il le connoît, \& déteste ce qui peut lui être défavorable." (D'Holbach, 1770, p. 51)

15 "La nature dans tous ses phénomenes agit nécessairement d'après l'essence qui lui est propre; tous les êtres qu'elle renferme agissent nécessairement d'après leurs essences particulieres."
} 
In the terrible convulsions which sometimes agitate political societies, and which often produce the overthrow of an empire, there is not a single action, a single word, a single thought, a single desire, a single passion in the agents which participate in the revolution as destructors or as victims, which is not necessary, which does not act as it ought to act, which does not infallibly produce the effects that it has to produce, according to the place which these agents occupy in this moral turmoil. This would seem evident for an intelligence that would be in a position to know and appreciate all the actions and reactions of the minds and the bodies of those who contribute to this revolution. (D'Holbach, 1770, p. 52). ${ }^{16}$

It is not clear that this claim, that it is theoretically possible to see how all the details of a revolution hang together in a necessary connection, based on a knowledge of the "minds and bodies" of the people who participate in it, is a consequence of the laws of physics. D'Holbach argues that all processes are reducible to matter and motion, but this does not necessarily mean that they are reducible to physics, since according to D'Holbach, matter can have different qualities of which he does not claim that they can all be understood in terms of physics. Therefore, he leaves open the possibility that the human body has properties which cannot be understood through the laws of physics: "Holbach is not a naturalist in the stricter sense of attempting to understand human beings in terms of the same laws that explain the rest of nature" (LeBuffe, 2010). ${ }^{17}$ Thus, the claim that perfect prediction of human behaviour is possible on the basis of perfect knowledge of mind and body does not seem to be based on determinism in physics, and the motivation for this claim must rather be sought in his philosophy.

The basic idea that there could be an intelligence capable of making perfect predictions can already be found in Leibniz; in the case of Leibniz, it is deeply embedded in his philosophical system. In (1702), Leibniz defends his doctrine of the preestablished harmony against criticism by Bayle, who has argued that it is absurd to think that a body could operate independently of the mind. Leibniz replies:

\footnotetext{
16 "Dans les convulsions terribles qui agitent quelquefois les sociétés politiques, \& qui produisent souvent le renversement d'un empire, il n'y a pas une seule action, une seule parole, une seule pensée, une seule volonté, une seule passion dans les agens qui concourent à la révolution comme destructeurs ou comme victimes, qui ne soit nécessaire, qui n'agisse comme elle doit agir, qui n'opere infailliblement les effets qu'elle doit opérer, suivant la place qu'occupent ces agens dans ce tourbillon moral. Cela paroitroit évident pour une intelligence qui seroit en état de saisir \& d'apprécier toutes les actions \& réactions des esprits \& des corps de ceux qui contribuent à cette révolution."

${ }^{17}$ Wolfe (2007, p. 38) makes a distinction between Laplacian determinism and Spinozistic determinism, where the former "emphasizes predictability, based on the laws governing the basic components of the universe and their interactions, and in that sense is purely physicalist", while the latter is a determinism in which "the nature of mind and action requires specific types of explanations." Wolfe classifies D'Holbach as a Laplacian determinist, but although D'Holbach indeed emphasizes predictability, he does so without referring to the reducibility of the processes of the mind to physics, and his view is quite compatible with the possibility that acts of the will, though deterministic, require special explanations and are not reducible to physics.
} 
There is no doubt that a man could make a machine which was capable of walking around a town for a time, and of turning precisely at the corners of certain streets. And an incomparably more perfect, although still limited, mind could foresee and avoid an incomparably greater number of obstacles. And this being so, if this world were, as some think it is, only a combination of a finite number of atoms which interact in accordance with mechanical laws, it is certain that a finite mind could be sufficiently exalted as to understand and predict with certainty everything that will happen in a given period. This mind could then not only make a ship capable of getting itself to a certain port, by first giving it the route, the direction, and the requisite equipment, but it could also build a body capable of simulating a man. (Leibniz, 1702, p. 243).

However, Leibniz added that the world is not a combination of a finite number of atoms, and therefore it takes an infinite mind to foresee all occurrences. ${ }^{18}$

We have seen that the so-called Laplacian determinism, the idea that it is possible in principle to make perfect predictions on the basis of perfect knowledge of the present state of the universe, did not originate in Laplace, and as this section has shown, the basic idea was not necessarily one that was coming from physics (although in Leibniz there is a strong connection between physics and philosophy).

\section{The principle of sufficient reason and the law of continuity}

We've seen in section 3 that Laplace's determinism is based on the principle of sufficient reason; to see how this principle relates to the possibility of mathematical descriptions of nature, we turn to one of the other authors who already stated something similar to Laplacian determinism before Laplace, namely Condorcet. Laplace was almost certainly influenced by Condorcet's determinism: Condorcet was an important intellectual influence on Laplace, and according to Hahn (2005, p. 50-51), Laplace carefully read the book in which Condorcet's argument for determinism appeared. The context of Condorcet's statement is a discussion about the distinction between necessary and contingent laws of nature. ${ }^{19}$ According to Condorcet, the necessary laws of nature are "necessary consequences of the idea that we have of matter" (Condorcet, 1768, p. 4). ${ }^{20}$ These laws form mechanics, which at the time was a part of mixed mathematics. The

\footnotetext{
${ }^{18}$ This infinite mind being God. Leibniz, in (1916 [1765], p. 51): "it belongs only to the supreme Reason, whom nothing escapes, distinctly to comprehend all the infinite and to see all the reasons and all the consequences. All that we can do in regard to infinities is to know them confusedly, and to know at least distinctly that they are such; otherwise we judge very wrongly of the beauty and the grandeur of the universe...."

${ }^{19}$ There was a debate about this issue at the time; see the preface in D'Alembert (1758).

20 "des conséquences nécessaires de l'idée que nous avons de la matiere".
} 
contingent laws of nature are those which God could have willed differently, and we can only know these laws empirically: to discover them, we must closely observe the phenomena in nature and submit the observations to calculation. According to Condorcet, Newton's law of gravitation belongs to the contingent laws of nature and thus does not belong to mechanics properly speaking. The contingent laws of nature constitute the Système du Monde. Condorcet argues that although many laws of nature are contingent, there is no contingency in the phenomena, which all follow necessarily from the laws of nature:

...if the law of continuity is not violated in the universe, one could regard its state at every instant as the result of what had to happen to matter once arranged in a certain order and then abandoned to itself. An Intelligence that would then know the state of all phenomena at a given instant, the laws to which matter is subjected, and their effects after a certain period of time, would have perfect knowledge of the System of the World. (Condorcet, 1768, p. 4-5). ${ }^{21}$

Condorcet does not specify which laws the intelligence needs for his perfect knowledge, but in any case, these can not only be the necessary laws which follow directly from our conception of matter, but also have to include contingent laws of nature. Thus, Condorcet's determinism is not based on mechanics, at least not in the narrow $18^{\text {th }}$ century sense in which mechanics is a branch of mixed mathematics; but this still leaves the possibility open that it is based on physics.

To get a better understanding of the foundations of Laplace's determinism, we have to look at the "law of continuity" to which Condorcet refers, and on which according to him the idea that the necessary consequence of the state of the universe at a previous instant depends. A description of this law can be found in the Encyclopédie of Diderot and D'Alembert:

Continuity, (law of) is a principle that we owe to M. Leibniz, and which teaches us that nature takes no leaps, and that a being never passes from one state into another, without passing through all the different states that one can conceive in between them. This law follows, according to M. Leibniz, from the axiom of sufficient reason. (Formey and d'Alembert, 1754, p. 116). ${ }^{22}$

\footnotetext{
21 "... si la loi de la continuité n'étoit point violée dans l'univers, on pourroit regarder ce qu'il est a chaque instant, comme le résultat de ce qui devoit arriver à la matiere arrangée une fois dans un certain ordre, \& abandonnée ensuite à elle-même. Une Intelligence qui connoîtroit alors l'état de tous les phénomenes dans un instant donné, les loix auxquelles la matiere est assujettie, \& leur effet au bout d'un tems quelconque, auroit une connoissance parfaite du Systême du Monde."

22 "Continuité, (loi de) c'est un principe que nous devons à M. Leibnitz, \& qui nous enseigne que rien ne se fait par saut dans la nature, \& qu'un être ne passe point d'un état dans un autre, sans passer par tous les différens états qu'on peut concevoir entr'eux. Cette loi découle, suivant M. Leibnitz, de l'axiome de la raison suffisante."
} 
In the Encyclopédie, the law of continuity is thus directly linked with Leibniz and the principle of sufficient reason; this supports the idea that there is a common background to Laplace's and Condorcet's determinism.

The law of continuity was a familiar principle in eighteenth century physics, and is usually attributed to Leibniz; it plays an important role in Leibniz' thought. Throughout Leibniz' work, one can find various formulations of the law, in the context of mathematics, physics, and metaphysics. The most familiar formulation of the law of continuity is the statement that "nature makes no leaps", that all transitions in nature are gradual, and that nothing can change from one state to another without passing through all the intermediary stages (Leibniz, 1916 [1765], p. 50). This principle implies that there can be no perfectly hard bodies, because the collision of two hard bodies would involve a discontinuous change in the direction of motion of the bodies (Leibniz, 1695, p. 170). In addition, Leibniz argues that the law of continuity implies that two individual things can never be exactly equal, because there are infinite gradations and variations (Leibniz, 1916 [1765], p. 51; see also Lovejoy, 1936, on the continuity of beings). Another version of the law of continuity that Leibniz gave is the principle that "If any continuous transition is proposed terminating in a certain limit, then it is possible to form a general reasoning, which covers also the final limit" (quoted in Schubring, 2005, p. 174). This is a mathematical principle, and it lies at the basis of Leibniz' calculus, because it guarantees that infinitesimals behave properly: if you take the limit from quantities of a very small but finite size to infinitely small quantities, nothing essential changes. It also implies that rest can be considered as infinitely small velocity; Leibniz demands that the laws of motion have to be consistent with this (Leibniz, 1687; Leibniz, 1695, p. 171).

The law of continuity is thus a general principle in Leibniz' system, with various implications in physics, mathematics, and metaphysics. Schubring (2005, p. 174) argues that although Leibniz gave both metaphysical and purely mathematical formulations of the law of continuity, it was the metaphysical version of the law that was picked up by his contemporaries and discussed throughout the eighteenth century: in particular, it played a central role in the debate about whether there could be perfectly hard bodies.

According to the Encyclopédie, Leibniz derived the law of continuity from the principle of sufficient reason. However, for Leibniz, there could only be an indirect connection between the principle of sufficient reason and the law of continuity: it is possible that the law of continuity does not hold, but there is a sufficient reason for it to hold in our world. According to Rutherford, "Leibniz describes the principle of continuity as a 'principle of general order', which obtains in the actual world as a consequence of God's wisdom. He thus explicitly connects it with God's choice of the best of all possible worlds." (Rutherford, 1995, p. 29, and see Leibniz, 1687, p. 52). But others during the eighteenth century drew a more direct relation between the principle of sufficient reason and the law of continuity. For example, Johann Bernoulli, who 
supported Leibniz' argument that hard body collisions would violate the law of continuity, gave the following justification of the law:

If nature could pass from one extreme to another, for example from rest to motion, from motion to rest, or from a motion in one direction to a motion in the opposite direction, without passing through all the imperceptible motions that lead from the one to the other, it should be the case that the first state is destroyed, without nature knowing what new state it must conform itself to; for, in the end, what reason could she have to prefer one, of which it could not be asked why this one rather than that one? Since there is no necessary connection between these two states, no passage from motion to rest, from rest to motion, or from a motion to a motion in the opposite direction, no reason could determine nature to produce one thing rather than any other (Bernoulli, 1727, p. 9). ${ }^{23}$

Bernoulli thus bases the law of continuity on the principle of sufficient reason in a more direct way than Leibniz: he argues that if there is a discontinuous change between states, there is no sufficient reason for the transition from one state to another. Therefore, the state at a certain instant must continuously determine subsequent states. A similar line of argument can be found in the Encyclopédie, where the connection between the principle of sufficient reason and the law of continuity is explained as follows:

For each state in which a being finds itself, there must be a sufficient reason why this being finds itself in this state rather than in any other; and this reason can only be found in the antecedent state. This antecedent state thus contained something which has given rise to the current state which has followed it; so that these two states are connected in such a way that it is impossible to put another one in between; because if there were a possible state between the current state and that which immediately preceded it, nature would have left the first state without already being determined by the second to abandon the first; there would thus not have been a sufficient reason why it would have passed to this state rather than to any other possible state. Thus no being passes from one state to another, without passing through the intermediary states; just as one does not go from one city to another without going over the road between them (Formey and D'Alembert, 1754, p. 116). ${ }^{24}$

\footnotetext{
${ }^{23}$ "Si la nature pouvoit passer d'un extrême à l'autre, par exemple, du repos au mouvement, du mouvement au repos, ou d'un mouvement en un sens à un mouvement en sens contraire, sans passer par tous les mouvemens insensibles qui conduisent de l'un à l'autre; il faudroit que le premier état fut détruit, sans que la nature sçût à quel nouvel état elle doit se déterminer; car enfin par quelle raison en choisiroit-elle un par préference, \& dont on ne pût demander pourquoi celui-ci plutôt que celui-là? Puisque n'y ayant aucune liaison nécessaire entre ces deux états, point de passage du mouvement au repos, du repos au mouvement, ou d'un mouvement à un mouvement oposé; aucune raison ne la détermineroit à produire une chose plutôt que toute autre."

24 "Chaque état dans lequel un être se trouve, doit avoir sa raison suffisante pourquoi cet être se trouve dans cet état plûtôt que dans tout autre; \& cette raison ne peut se trouver que dans l'état antécédent. Cet état
} 
Like Laplace, the Encyclopédie uses a notion of the principle of sufficient reason that deviates from Leibniz' version: it is about how something is brought about, about the efficient cause of the state of a certain being. Laplace had claimed that the idea that the state of the universe is the cause of the state at the next instant followed from the principle of sufficient reason. Here, we see how the argument can be spelled out in more detail with the law of continuity as an intermediary step. There can be no sudden jump or discontinuity between one state and the next, because in that case, there would be no sufficient reason for the transition from one state to the other, there would be an unexplainable gap. Therefore, the state at the universe at a certain instant continuously determines subsequent states, through infinitesimal steps, and in this way, one can say that the state of the universe is the cause of the state at the next instant.

It is important to note that this is a stronger requirement than determinism, in the sense that according to this requirement, it is not enough that there are laws which determine how subsequent states relate to each other: such laws could still allow for discontinuous changes in certain variables. Rather, there has to be a "necessary connection" between states, in the sense that one state is the continuously producing cause of the following state, and states follow each other without gaps. In this view, hard body collisions are excluded: even if these collisions are perfectly deterministic, they still involve a discontinuous change in the direction of motion. This is the reasoning behind Laplace's claim that the principle of sufficient reason implies that the state of the universe is the cause of the state at the next instant, and we see that it is a type of reasoning that is quite foreign to modern physics, in which there is no such rigorous exclusion of discontinuities.

Thus, the argument for determinism that can be reconstructed from historical sources is that the principle of sufficient reason implies that there is a continuity between states, and that this implies that the state of the universe is the cause of the state at the next instant, and in this way it implies determinism. This is a completely general philosophical argument, and the whole story of the background of Laplace's determinism can thus be told without referring to mathematics or the equations of mechanics. However, this does not imply that there is no connection. For Leibniz, the law of continuity plays a central role in the foundations of differential calculus and it lies at the basis of the application of differential calculus to physics: only when it is guaranteed that variables in nature change in a continuous manner, can differential calculus be applied successfully. Thus, the principles which underlie the idea that the

antécédent contenoit donc quelque chose qui a fait naître l'état actuel qui l'a suivi; ensorte que ces deux états sont tellement liés, qu'il est impossible d'en mettre un autre entre deux: car s'il y avoit un état possible entre l'état actuel \& celui qui l'a précédé immédiatement, la nature auroit quitté le premier état, sans être encore déterminée par le second à abandonner le premier; il n'y auroit donc point de raison suffisante pourquoi elle passeroit plûtôt à cet état qu'à tout autre état possible. Ainsi aucun être ne passe d'un état à un autre, sans passer par les états intermédiaires; de même que l'on ne va pas d'une ville à une autre, sans parcourir le chemin qui est entre deux." 
state of the universe is the cause of the state at the next instant, also underlie the idea that the evolution of physical systems can be described by differential equations. Cassirer (1956 [1936], p. 5) captures this dual aspect of Laplacian determinism when he writes that "the Laplacian formula is as capable of a scientific as of a purely metaphysical interpretation, and it is precisely this dual character that accounts for the strong influence it exercised".

Furthermore, as we have seen in section (2), it turned out in the course of the nineteenth century that the equation of motion of a system can fail to have a unique solution if it involves a force that is non-Lipschitz-continuous; although this could not yet be spelled out at the time of Laplace (among others because there was not yet a clear notion of continuity of functions in mathematics), it is possible that he had a general, not mathematically precise idea that differential equations could fail to have unique solutions if they involved discontinuities of some sort.

Thus, the law of continuity, which played a role in the general argument for determinism, was also at the basis of the use of differential equations in physics and of the expectation that these equations would have unique solutions.

\section{Conclusion}

I have argued that Laplace's determinism was based on a re-interpretation of Leibniz' principle of sufficient reason and the law of continuity, rather than on his mechanics. To say that Laplace's determinism was not based on mechanics, is of course not to say that physics was wholly irrelevant to his idea of determinism. Although it was not possible for Laplace to give a strict mathematical derivation of determinism in the equations of physics, no conflicts with determinism were encountered in physics (except Poisson's theoretical example of an indeterministic system, which was an implausible system to occur in reality, and it is unknown whether Laplace was aware of it), and although it could not be proven that the equations of physics would always have unique solutions, this did seem plausible. It is also not to say that Laplace's determinism was unfounded or based on prejudice. There may be good reasons to appeal to the principle of sufficient reason; but regardless, the law of continuity had independent plausibility and played a significant role in eighteenth century physics. And in a sense, the law of continuity still plays a role in the present discussion of determinism in classical mechanics: it has been argued that the Norton dome may not be a "proper Newtonian system" because it involves a discontinuity in the shape of the dome (Malament, 2008). 
The idea that perfect prediction is possible in principle on the basis of calculation and perfect knowledge of the world did not originate in Laplace, and it was not directly derived from the laws of physics. But significantly, the idea did come up in a time when big steps were being made in the application of differential calculus to physics.

\section{Acknowledgements}

Many thanks to Charles Wolfe, Iulia Mihai, Eric Schliesser, John Norton, Mark Wilson, Jos Uffink, Jeremy Butterfield, Nicholas Rescher and an anonymous referee, for helpful comments and discussion.

\section{References}

Arnold, V. I. (1989). Mathematical methods of classical mechanics (K. Vogtmann \& A. Weinstein, Trans.) ( $2^{\text {nd }}$ ed.). New York: Springer.

Bernoulli, J. (1727). Discours sur les loix de la communication du mouvement. In J. Bernoulli, Opera Omnia (vol. 3, pp. 7-107). Lausanne and Geneva: Sumptibus Marci-Michaelis Bousquet \& Sociorum.

Boscovich, R. J. (1922 [1763]). A theory of natural philosophy (Latin-English edition). Chicago/ London: Open Court publishing company.

Boussinesq, J. (1879). Conciliation du véritable déterminisme mécanique avec l'existence de la vie et de la liberté morale. Mémoires de la société des sciences, de l'agriculture et des arts de Lille, 6(4), 1-257.

Cassirer, E. (1956 [1936]). Determinism and indeterminism in modern physics (O. T. Benfey, Trans.). New Haven: Yale University Press.

Condorcet, N. de (1768). Essais d'analyse: Lettre dite du marquis de Condorcet à M. d'Alembert, sur le système du monde et le calcul intégral. Paris: Imprimerie de Diderot.

D'Alembert, J. le Rond (1758). Traité de dynamique ( $2^{\text {nd }}$ ed.). Paris: Chez David, Libraire.

Daston, L. (1992), The doctrine of chances without chance: determinism, mathematical probability, and quantification in the seventeenth century. The Invention of Physical Science - Boston Studies in the Philosophy of Science, 139, 27-50.

D'Holbach, P. H. T. (1770). Système de la nature ou des lois du monde physique et du monde moral (Vol. 1) (published under the name Mirabaud). London (actually Amsterdam).

Diderot, D. (1951). Inventaire du fonds Vandeul et inédits de Diderot (H. Dieckmann, Ed.). Genève: Droz.

Earman, J. (1986). A primer on determinism. Dordrecht: Reidel.

Formey, J. H. S. \& D'Alembert, J. le Rond (1754), "continuité (loi de)". In D. Diderot \& J. le Rond D'Alembert (Eds.), Encyclopédie, ou dictionnaire raisonné des sciences, des arts et des métiers, etc, vol. 4, pp. 116-117. University of Chicago: ARTFL Encyclopédie Project, R. Morrissey (Ed.) (Spring 2013 edition). http://encyclopedie.uchicago.edu/.

Hacking, I. (1983). Nineteenth century cracks in the concept of determinism. Journal of the history of ideas, 44(3), 455-475.

Hahn, R. (2005). Pierre Simon Laplace, 1749-1827: A determined scientist. Cambridge, Massachusetts: Harvard University Press. 
Israel, G. (1992). L'histoire du principe du déterminisme et ses rencontres avec les mathématiques. In A. Dahan Dalmedico, J.-L. Chabert \& K. Chemla (Eds.), Chaos et déterminisme. Paris: Éditions du Seuil.

Kline, M. (1972). Mathematical thought from ancient to modern times. New York: Oxford University Press.

Landau, L. D. \& Lifshitz, E. M. (1976). Mechanics - Course of theoretical physics, vol. 1 ( J. B. Sykes \& J. S. Bell, Trans.) ( $3^{\text {rd }}$ ed.). Oxford: Pergamon.

Laplace, P. S. (1772a). Recherches sur le calcul intégral et sur le système du monde. CEuvres Complètes, 8, pp. 369-477.

Laplace, P. S. (1772b). Mémoire sur les solutions particulières des équations différentielles et sur les inégalités séculaires des planètes. CEuvres complètes, 8, pp. 325-366.

Laplace, P. S. (1773). Recherches sur l'intégration des différentielles aux différences finies et sur leur application à l'analyse des hasards. Mémoires de mathématiques et de physiques présentés à l'Académie Royale des Sciences par divers savants, vol 7, pp. 113-114. CEuvres Complètes, 8, pp. 144-145.

Laplace, P. S. (1779). Mémoire sur les suites. CEuvres complètes, 10, pp. 1-89.

Laplace, P. S. (1814). Essai philosophique sur les probabilités. Paris: Courcier.

LeBuffe, M. (2010). Paul-Henri Thiry (Baron) d'Holbach. In E. N. Zalta (Ed.), The Stanford Encyclopedia of Philosophy (Fall 2010 Edition). http://plato.stanford.edu /archives/fall2010/entries/holbach/.

Leibniz, G. W. (1687). Lettre de M. L. sur un principe general utile à l'explication des loix de la nature par la consideration de la sagesse divine, pour servir de replique à la reponse du R. P. D. Malebranche. Nouvelles de la republique des lettres, July 1687. Philosophische Schriften, vol. 3, pp. 51-55.

Leibniz, G. W. (1695). Specimen dynamicum: an essay in dynamics. In G. W. Leibniz: Philosophical texts (1998) (R. Francs \& R. S. Woolhouse, Trans.), pp. 153-179. Oxford University Press.

Leibniz, G. W. (1702). Reply to the comments in the second edition of M. Bayle's Critical Dictionary, in the article 'Rorarius', concerning the system of pre-established harmony. In G. W. Leibniz: Philosophical texts (1998) (R. Francs \& R. S. Woolhouse, Trans.), pp. 241253. Oxford University Press.

Leibniz, G. W. (2007 [1710]). Theodicy. (E. M. Huggard, Trans.). Bibliobazaar.

Leibniz, G. W. (1714). Principles of nature and grace, based on reason. In G. W. Leibniz: Philosophical texts (1998) (R. Francs \& R. S. Woolhouse, Trans.), pp. 258-266. Oxford University Press.

Leibniz, G. W. (1916 [1765]). New essays concerning human understanding (A. G. Langley, Trans.). Chicago/London: The open court publishing company.

Lipschitz, M. R. (1876). Sur la possibilité d'intégrer complétement un système donné d'équations différentielles. Bulletin des sciences mathématiques et astronomiques, (1)10, pp. 149-159.

Lovejoy, A. O. (1936). The great chain of being. Cambridge, Massachusetts, and London, England: Harvard University Press.

Malament, D. B. (2008). Norton's Slippery Slope. Philosophy of Science, 75, pp. 799-816.

Maupertuis, P. L. (1756). Sur la divination. In Eeuvres de Maupertuis, vol. 2, pp. 330-338.

Melamed, Y. \& Lin, M. (2013). Principle of sufficient reason. In E. N. Zalta (Ed.), The Stanford Encyclopedia of Philosophy (summer 2013 edition). http://plato.stanford.edu/ archives/sum2013/entries/sufficient-reason/. (Accessed 10 July 2013).

Morando, B. (1995). Laplace. In R. Taton \& C. Wilson (Eds.), Planetary astronomy from the renaissance to the rise of astrophysics, part B, pp. 131-150. Cambridge: Cambridge University Press.

Norton, J. (2008). The dome: an unexpectedly simple failure of determinism. Philosophy of Science, $75,786-98$. 
O'Connor, J. J. \& Robertson, E. F. (2002). Siméon Denis Poisson. In MacTutor History of Mathematics Archive. http://www-history.mcs.st-and.ac.uk/Biographies/Poisson.html. (Accessed 10 July 2013).

Poisson, S. D. (1806). Mémoire sur les solutions particulières des équations différentielles et des équations aux différences. Journal de l'École Polytechnique, vol. 6, cahier 13, pp. 60-125.

Rutherford, D. (1995). Leibniz and the rational order of nature. Cambridge: Cambridge University Press.

Schliesser, E. (forthcoming). Spinoza and the philosophy of science: mathematics, motion, and being. In M. Della Rocca (Ed.), Oxford handbook of Spinoza. Oxford: Oxford University Press.

Schubring, G. (2005). Conflicts between generalization, rigor, and intuition: number concepts underlying the development of analysis in $17^{\text {th }}-19^{\text {th }}$ century France and Germany. New York: Springer.

Stiegler, K. (1974). On the origin of the so-called Laplacean determinism. In Actes du XIIIe congrès international d'histoire des sciences, 1971, vol. 6, pp 307-312. Moscow.

Truesdell, C. (1960). The rational mechanics of flexible or elastic bodies, 1638-1788. In L. Euleri Opera Omnia, Ser. II, Vol. 11, part 2. Zürich: Orell-Füssli.

Van Strien, M. (2014). The Norton dome and the nineteenth century foundations of determinism. Journal for General Philosophy of Science, 45(1), pp. 167-185.

Wolfe, C. T. (2007). Determinism/Spinozism in the Radical Enlightenment: the cases of Anthony Collins and Denis Diderot. International Review of Eighteenth-Century Studies, 1(1), pp. 3751.

Wolfe, C. T. (2012). Determinism and action in the radical enlightenment. Manuscript. 